УДК 622.692

\section{WELDING RENOVATION OF SUPPORTING UNITS IN GAP-CROSSING PIPELINE STRUCTURES}

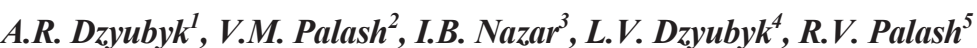

Existing elements of overpass's supporting units in pipeline transport had been analyzed. Also in this project operational loads that occur in areas of land pipelines were studied using a mathematical model that takes into account the possibility of vertical displacement supporting structure. Proposed to use welded $I$-beam section as a cross-bar for support. Calculation of selected beams and selection geometrical sizes of elements depending on the applied load were done. We have analyzed the influence of welding cycle on the formation of stress and deformation occurring at manufacturing of metal cross-bar $I$-section.

Keywords: support, pipeline, tension, welded joint, strength, bearing capacity.

Introduction and urgency of the problem. Pipeline overpasses occupy $2 \%$ of the total length of pipelines, what is quite small amount. But they greatly affect the total performance of the system.

Gap-crossing structures or pipeline bridges serve to avoid major natural or man-made obstacles, such as steep cliffs, deep ravines, large boulders, swampy areas, roads or railways. Supporting units must be not just strong enough to support the pipeline (weight of the pipes and liquids or gases in it etc.), but also must be strong enough to face the influence of the external factors (the influence of the environment, axial position, subsidence of pillars etc.) Last can greatly change tensions that can lead to cracks $[1,2]$

Usage of standard building components and their installation schemes do not always satisfy the operating conditions, especially in potentially dangerous areas like mountain massifs. There may be a slight overload cross-bars supporting units support pipeline. In particular, under the influence of temperature changes (daily and seasonal), changes in operation modes pipelines all that can lead to horizontal and vertical movement of pipes leading to cracking (Fig 1, a) and fracture of standard concrete structures (Fig. 1, b).
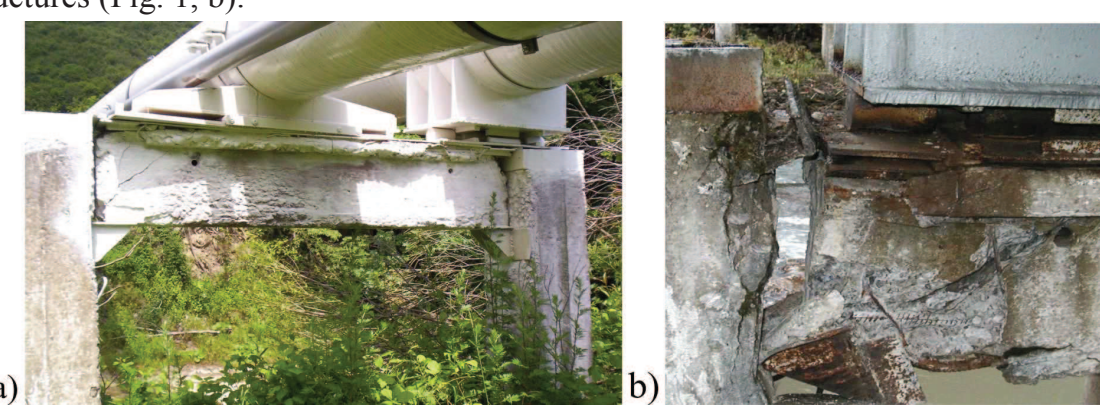

Fig. 1 gap-crossing supporting unit [4]: a) cracks in concrete cross-bar; b) cross-bar fracture

доц. А.Р. Дзюбик, канд. техн. наук - НУ "Львівська політехніка"; проф. В.М. Палаш, канд. техн. наук - НУ "Львівська політехніка"; доц. І.Б. Назар, канд. техн. наук - НУ "Львівська політехніка"; 4 Л.В. Дзюбик, канд. техн. наук - НУ "Львівська політехніка"; 5 доц. Р.В. Палаш, канд. техн. наук - НУ "Львівська політехніка"
One way to restore supporting unit are installing on them a metal casing caps that are connected to metal bolt $[4,5]$ After removal of the destroyed concrete beam, metal cylindrical structure was installed. However, the question of choice is not disclosed. It is known [6] that complex beam cross section are used more often. They take into consideration specifics conditions (presence of a significant cross-load), and the cost of materials and complexity of manufacturing is more economical compared to other types.

Main task and object of the work. In designing beam engineering structures static calculation scheme must be performed. We have to determine the estimated efforts of the load and make constructive design that would satisfy the requirements of strength, stiffness, durability and operating conditions. Taking into account the conditions of a cross-bar [1-4] and system of loadings metal welded $I$-beam should be used. It is important to evaluate the welding deformation of the structure.

Main part. Installing duty operation perform for lifting the pipeline to replace the cross-bars. Thus there is a change of reactions in towers and redistribution of bending moments at least in two adjacent runs.

In this project mathematical model is used that represents the pipeline in the form of a continuous beam many supporting beams, mounted on bearings with the possibility of vertical adjustment $[7,8]$. To determine the moments and reactions of towers a system of linear algebraic equations were used derived from the conditions of equality beam deflection, elastic movement of supports and conditions of the balance of forces and moments:

$$
\begin{gathered}
\sum_{i=1}^{N_{R}} R_{i}\left(L-a_{i}\right)+\sum_{k=1}^{N_{P}} P_{k}\left(L-c_{k}\right)+\sum_{j=1}^{N_{q}} q_{j} \Delta_{j}\left(L-b_{j}^{0}\right)=0, \\
\sum_{i=1}^{N_{R}} R_{i}+\sum_{k=1}^{N_{P}} P_{k}+\sum_{j=1}^{N_{q}} q_{j} \Delta_{j}=0,
\end{gathered}
$$

$w_{0}+\theta_{0} a_{i}+\sum_{m=1}^{N_{R}} R_{m} \theta\left(a_{i}-a_{m}\right) K\left(a_{i}, a_{m}\right)+\kappa_{i} R_{i}=z_{i}-\sum_{k=1}^{N_{P}} P_{k} \theta\left(a_{i}-c_{k}\right) K\left(a_{i}, c_{k}\right)-\sum_{j=1}^{N_{q}} q_{i} H_{j}\left(a_{i}\right)$. (3) where $a_{i}, \kappa_{i}, z_{i}, i=1, N_{R}$ - coordinates, compliance rates and the initial position supports; $\left[d_{m}, d_{m+1}\right), m=1,2, \ldots, \mathrm{N}_{D}$ - some parts of the flyover pipeline where the bending rigidity $D_{m}=\left(\pi d_{T m}^{3} \delta_{m} E_{m}\right) / 8$ is constant, $d_{T m}, \delta_{m}, E_{m}$ diameter, thickness and Young's modulus of deflection; at points $c_{k}, k=1,2, \ldots, N_{p}$ concentrated loads act on the pipeline $P_{k}$, and at $\left[b_{j}, b_{j+1}\right), j=1, N_{q}$ (within the areas of a constant rigidity) distributed load of constant intensity $q_{j}$. Than $\Delta_{j}=b_{j+1}-b_{j}$ Sustainable length of the load, and $b_{j}^{0}=\left(b_{j+1}+b_{j}\right) / 2$ - their centers; $R_{i}, i=\overline{1, N_{R}}-$ supports reaction; $\delta(x)$ - Dirac function, $\theta(x)$ - Heaviside function; $K(x, \alpha)$ - Cauchy function; $w_{0}, \theta_{0}, M_{0}, Q_{0}$ initial parameters of deflection, angle of rotation, bending moment and power of section; $H_{j}(x)$ - Cauchy integral of the function.

Using equation (1)-(3) we can get the necessary information to perform repair work. For this we use the results of pipeline inspection (the reaction of some sup- 
ports, their relative spatial location and position of the axis of the pipeline). It is actual for the case of study sites of pipes adjacent to the ground where their elastic interaction leads to reduction in the burden on the edges of the pipe and the corresponding increase on neighboring pillars. This pipe is considered as a system of finite rod elements mounted on elastic bearings [7].

Analysis of the results showed that the value of reactions supports changes in the operating and repairing load may significantly grow. When designing pipelines or performing their repair the value of supports reactions ranging from $50 \mathrm{kN}$ to $100 \mathrm{kN}$. The influence of external factors such as landslides, supports compliance etc. increase this amount to $200 \mathrm{kN}$.

Conditions of design. Consider the design of welded beam length $1=$ $5500 \mathrm{~mm}$, which is free on supports. Because of the significant burden and advice literature $[3,6]$ will use structural steel brand 15 ХСНД that has now foreign analogs. It is characterized by good technological weldability and not prone to cracking as a result of the thermal cycle of welding. Allowable stress factors based on the conditions 0.9 and set overload $n=1,2$ at $[\sigma] p=225 \mathrm{MPa}$. Beam cross-bar evenly loaded with its own weight $(q)$ and two point loads $(P)$ of pipelines (Fig. 2). The distance between the axes of the pipes is $2.5 \mathrm{~m}$, they are located symmetrically relative to the center of cross-bar. Due to the influence of natural factors pipes can do transverse movement. The largest beam deflection of cross-bar (f) shall not exceed 1/500 of its length. Planning is done on the basis of existing pressures, the possibility of transverse displacement of pipes and provision of general and local strength. The size of the load $(P)$ taken as $100 \mathrm{kN}$

Calculation of loads from concentrated forces carried out we take like one of the pipes is located above the top line of influence and that is $M_{\Sigma}=0,227 \mathrm{MNm}$. This line spur of the moment and transverse forces built to analyze possible cases of pipe displacement across cross-bars in the transverse direction.

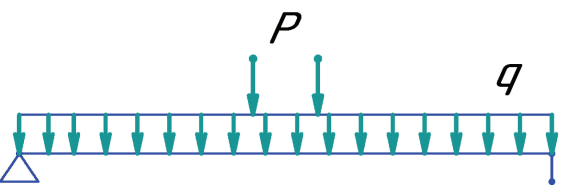

Fig. 2 Calculation of loads in the beam, $P, q$-load from pipe weight and cross-bar

Then resistance torque, taking into account the allowable stress, will be $W=0,000677 \mathrm{~m}^{3}$. The total value of the transverse force concentrated and evenly distributed loads equal $Q_{\Sigma}=156,33 \mathrm{kN}$.

Designing of cross-bar welded beam. The lowest elevation beam stiffness of conditions - is $\frac{f_{\max }}{l}=\frac{1}{500}$ (Fig. 3, a). After consideration of allowable stresses and geometrical characteristics of beam get the following relationship [7, 8]: $\frac{h}{l}=0,8[\sigma]_{p} \cdot l\left[1-(4 / 3)(a / l)^{2}\right] /(4 E f)=0,096$. Then, for the length of cross-bar $5.5 \mathrm{~m}$, its height by stiffness will be $0.53 \mathrm{~m}$. To determine the height of the smallest section, you must know the thickness of the vertical sheet. For this purpose, the follo- wing approximate equation is used: $\delta_{B}=\frac{\sqrt{10 \cdot h}}{12,5}=5,828 \approx 6 \quad \mathrm{~mm}$. than $h=(1,3 \div 1,4) \sqrt{M / \delta_{B} \cdot[\sigma]_{p}}=(0,437 \div 0,471) \mathrm{m}$.

Since the resulting value is greater than the required minimum, we take the height of the vertical wall $\left(h_{B}\right)$ equal to $0.5 \mathrm{~m}$. It takes into account the installation of two shelves designed for $I$-section. Using the previous calculations, you can set the required cross-sectional area of a shelf: $F=850 \mathrm{~mm}^{2}$. Then, accordingly, its thickness $\left(\delta_{p}\right)$ will be $10 \mathrm{~mm}$, and the width $\left(\mathrm{s}_{p}\right) 85 \mathrm{~mm}$. The resulting geometric characteristics of beam cross-bar shown in Fig. 3 b.

Checking for most normal stress in the surface layer of the beam: $\sigma_{\max }=\frac{M}{I} y_{\max }=229,1 \mathrm{MPa}$ and tangential tension at gravity center of the beam in its reference section: $\tau=\frac{Q S}{I S_{B}}=60,8 \mathrm{MPa}$. This means that the construction satisfies the conditions of strength.

Sustainability of the beam is achieved welding of stiffeners to the vertical wall. We accept the distance between the stiffeners: $a=1,5 \cdot h_{B}=1,5 \cdot 0,5=0,75 \approx 0,8 \mathrm{~m}$. To test the stability of the wall you must consider the stiffeners, and then determine the critical stress and stability check of the construction $[6,8]$. Here, the normal stress in the surface layer of the vertical sheet is $\sigma_{1}=229,1 \mathrm{MPa}$.

Average tangential tension of transverse forces in the middle run is: $\tau=\frac{Q}{h_{B} \delta_{B}}=18,18 \mathrm{MPa}$. Local tension $\sigma_{m}$ under concentrated force (Fig. 3, c): $\sigma_{m}=\frac{P}{\delta_{B} z}=152,8 \mathrm{MPa}$. The value of the notional length $(z)$, which concentrated load from the effects of a pipeline is divided in the vertical wall of cross-bar: $z=3,25 \cdot \sqrt[3]{\frac{I_{n}}{h_{n}}}=5,45 \mathrm{~cm}$.

To verify the installation stiffeners (Fig. 3, d) use is recommended in the literature $[6,8]$ following equation:

$$
\sqrt{\left(\frac{\sigma}{\sigma_{o}}+\frac{\sigma_{m}}{\sigma_{M o}}\right)^{2}+\left(\frac{\tau}{\tau_{o}}\right)^{2}} \leq 1
$$

where $\sigma_{o}$ - normal stress on the upper edge of the vertical sheet $\tau_{o}$ - the average tangential stress, $\sigma_{M o}$ - factors that take into account the geometric characteristics of the projected beam cross-bar.

Applying appropriate expression [6,8], found that $\sigma_{o}=600 \mathrm{MPa} ; \tau_{o}=233,4$ $\mathrm{MPa} ; \quad \sigma_{M o}=533,8 ; \quad \sigma_{m}=152,8 \quad \mathrm{MPa} \quad$ and $\tau=18,8 \quad \mathrm{MPa}$, means $\sqrt{\left(\frac{229,1}{600}+\frac{152,8}{533,8}\right)^{2}+\left(\frac{18,8}{233,4}\right)^{2}}=0,672<1-$ vertical sheet resistance in the middle of a 
span is provided. Similarly, the test performed in other sections of the supporting pipe-centers.

Design of welded joints. Legs upper and lower joints is taken equal to the thickness of the vertical wall, $K=6 \mathrm{~mm}$ (Fig. 3, d). In the lower joints are tangential stress: $\tau=\frac{Q \cdot S}{0,7 \cdot 2 \cdot I \cdot K}=52,1 \mathrm{MPa}$. Here $Q-$ the largest force in the transverse beam, $S$ - static moment relative to the center of gravity, $I$ - inertia moment the beam. Despite the fact that the working tension low, legs length is not changed. In the upper joints, to the calculated stresses added value $\left(\tau_{p}\right)$ from the concentrated power P. Local tensions at the joint $K=6 \mathrm{~mm}$ and the coefficient (n), equals the following: $\tau_{p}=\frac{n \cdot P}{2 \cdot z \cdot 0,7 \cdot K}=87,3 \mathrm{MPa}$. Allowable stresses in lap joints determine the value of $\left[\tau^{\prime}\right]=0,65 \cdot[\sigma]_{p}=146 \mathrm{MPa}$. Conditions strength: $\tau_{p e s} \leq\left[\tau^{\prime}\right]$ for designed welded joints $\left(\tau_{p e 3}=\sqrt{\tau^{2}+\tau_{p}^{2}}=90,4 \mathrm{MPa}\right)$. Legs of stiffeners joints accept the same.
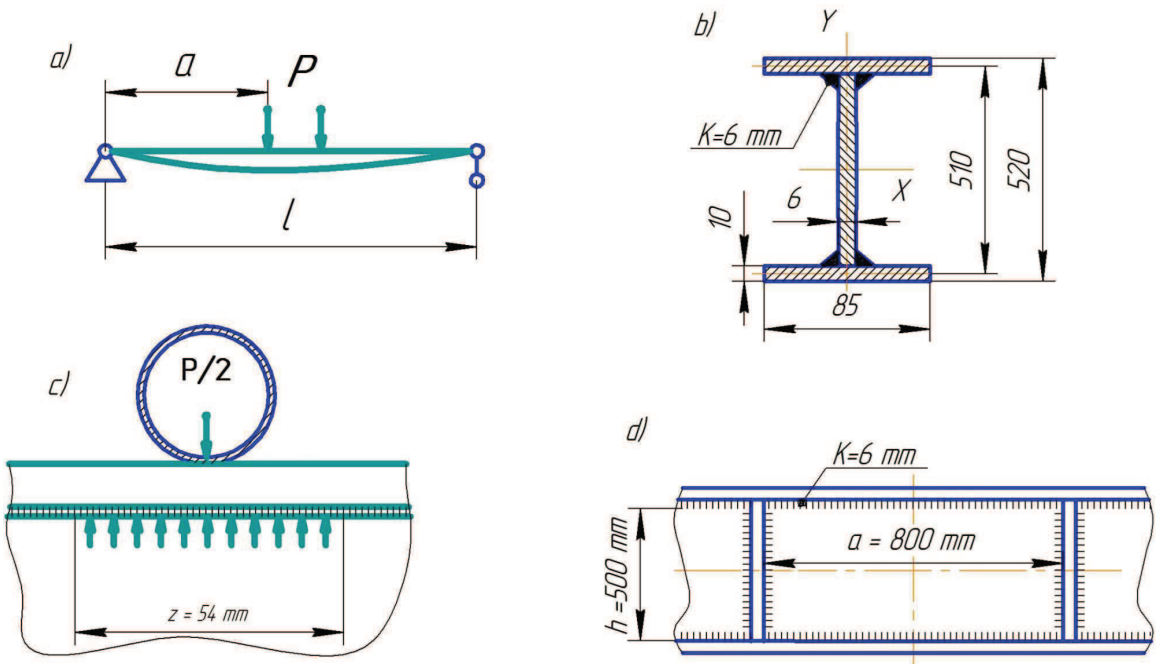

\section{Fig. 3. Calculation welded beams geometric parameters:}

a) calculation the height of the beam depending on the stiffness conditions.

b) chosen profile of beams; c) taking into account the local influence of concentrated force made by weight of pipeline; d) the location of the beam stiffeners

Definition shrink force and deformation. When welding stresses and deformations can affect the geometric dimensions of welded construction [9, 10]. For T (I)beams is the most significant bending. They are caused by shrinkage of longitudinal joints. If first perform welding $T$-beam and then $I$-beam the deformation of deflection have to be find each weld separately. The difference between the obtained values will cause the resulting deflection. Automatic submerged arc method recommended for this type of structures [6]. Based on recommendations of literary data [9], to determi- ned weld legs $(6 \mathrm{~mm})$, accept that the welding current $\left(I_{w d}\right)=450 \mathrm{~A}$; Voltage $\left(U_{\text {arc }}\right)=$ $34 \mathrm{U}$; welding speed $(V) 40 \mathrm{~m} / \mathrm{h}$; efficiency $(\zeta)=0,9$.

Determine where the heat spreads from the welding heat source: $\delta_{0}=2 \delta_{p}+\delta_{B}=2 \cdot 10+6=26 \mathrm{~mm}$. Then brought linear welding energy is: $q_{0}=\frac{I U \eta}{V \delta_{0}}=4766 \mathrm{~J} / \mathrm{cm}^{2}$. The dimensions of the active area by the Troche's method $[10,11]: b_{n}=b_{1}+b_{2}$, where $b_{1}, b_{2}$ - width heating to plastics and elastic-plastic deformation in element.

Here: $\quad b_{1}=\frac{0.484 q_{0}}{c \gamma T^{*}}, C \gamma-$ volumetric heat capacity, $\mathrm{j} /\left(\mathrm{cm}^{3}{ }^{\circ} \mathrm{C}\right)$, for steels $\left.5,2 \mathrm{j} /\left(\mathrm{cm}^{3}{ }^{\circ} \mathrm{C}\right)\right), b_{2 i}=K_{2}\left(h_{i}-b_{1}\right), i=1,2 ; h_{i}-$ width of areas where heat spreads; $T^{*}-$ temperature loss of stability of material ( $T^{*}=600$ for low-alloy steels). If $h_{i}>30 \mathrm{~cm}$, than $b_{2 i}$ is: $b_{2 i}=K_{2}\left(30-b_{1}\right)$. Coefficient $K_{2}$ depends on $q_{0}$ and is calculated by the formula [11]: $K_{2}=7.143 \cdot 10^{-2}+0.2086 \cdot 10^{-2} \cdot q_{0} \cdot 10^{-3}-0.054 \cdot 10^{-4} \cdot q_{0} \cdot 10^{-3}$.

So, $K_{2}=0.133$. Then to the left and right sides of the shelf beams, for shelves of $I$-beams $b_{2 L S h}=b_{2 R S h}=0.133 \cdot(14-4.9)=1.21 \mathrm{~cm}$. For vertical $h_{i}>30 \mathrm{~cm}$, than $b_{2 B}=0,133 \cdot\left(30-b_{1}\right)=3.33 \mathrm{~cm}$.

Then to the left and right sides of the shelf beams for shelves.

$$
F_{N}=\left(2 b_{1}+2 b_{2 \Pi}+\delta_{B}\right) \delta_{\Pi}+\left(b_{1}+b_{2 B}\right) \delta_{B}+K^{2},
$$

where $K^{2}$-sectional area of welds $T$-beam. So, $F_{N}=401,5 \mathrm{~mm}^{2}$. Then reactive tensions by the Troche's method [10] equal: $\sigma_{P}=\frac{\sigma_{T} \cdot F_{N}}{F-F_{N}}$, where $\sigma_{T}$ - proportional limit of material $\left(\sigma_{T}=350 \mathrm{MPa}\right) ; F$-sectional area (for $T$-beam $\left(F_{m}\right) 3850 \mathrm{~mm}^{2}$ and for $I-$ beam $\left.\left(\mathrm{F}_{\mathrm{I}}\right) 4700 \mathrm{~mm}^{2}\right)$. Then reactive tensions for $T$-beam $\sigma_{P T}=40,75 \mathrm{MPa}$; and $\sigma_{P I}=32,68 \mathrm{MPa}$ for $I$-beam.

The obtained values allow to calculate the longitudinal shortening of beams:

$$
\Delta \Delta_{\text {Short. }}^{\text {longitinal }}=\frac{P_{\text {shrinkage }}^{\text {longitual }} \cdot l}{E \cdot F},
$$

where $l$ - the length of the beam $(5500 \mathrm{~mm}) ; P_{\text {shrinkage }}^{\text {lonitulinal }}=\left(\sigma_{T}+\left|\sigma_{P}\right|\right) \cdot F_{n}-$ shrink force of longitudinal shortening; $E$ - Young's modulus.

Then we get that $T$-Beam shrink force $\left(P_{\mathrm{T}-\text {-beam.shrinkage }}^{\text {longi }}\right)$ is $159,93 \mathrm{kN}$ for the longitudinal reducing $\left(\Delta \Delta_{\text {Short_of }}^{\text {lonitulinal }} T\right.$-beam $) 1,067 \mathrm{~mm}$, and for $I$-beam $P_{I-\text { beamshrinkage }}^{\text {long. }}=$ $154,16 \mathrm{kN}$ and $\Delta \Delta_{\text {Short of }}^{\text {longitibeam }}=0,856 \mathrm{~mm}$.

The next step is to determine the center of gravity of welding elements and their active zones. This will help determine the bending moments during welding. (Fig. 4): $M_{x}=P_{\text {shrinkage }}^{\text {lonitulina }} e_{y}$, where $e-$ eccentricity (distance from the center of mass

3. Технологія та устаткування лісовиробничого комплексу 
the active zone to the center of gravity of the cross section of welded construction): for $T$-beam $189,9 \mathrm{~mm}$, for $I$-beam $246,2 \mathrm{~mm}$.

Thus, the bending moments as a result of shrinkage forces are: for $T$-beam $M_{\mathrm{x} T}=29793 \mathrm{~N} \cdot \mathrm{m}$ an $M_{\mathrm{xI}}=37829 \mathrm{~N} \cdot \mathrm{m}$ for $I$-beam. From here you can find the deflection figures $\left(I_{x}\right)$ from the cross-sectional moment of: $f_{\mathrm{y}}=\frac{M_{x} \cdot l^{2}}{8 \cdot E \cdot I_{x}}$. for $T$-beam $\left(f_{\mathrm{y} \mathrm{T}}\right)$ is $13,24 \mathrm{~mm}$, and for $I$-beam $\left(f_{\mathrm{yI}}\right)-5,52 \mathrm{~mm}$
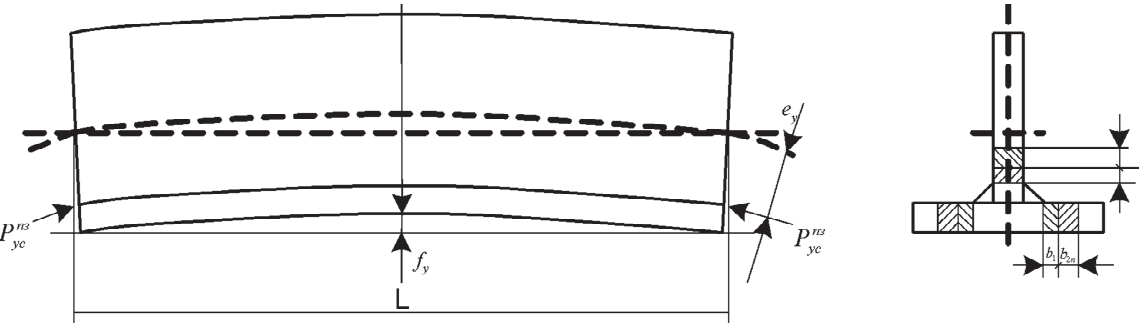

Fig. 4 Calculation of T-beam deflection

Then we get the following definition of total deflection:

$$
f_{\mathrm{y} \Sigma}=f_{\mathrm{y} \mathrm{T}}-f_{\mathrm{y} \mathrm{I}}=7,72 \mathrm{~mm} \text {. }
$$

Bending tensions that caused by this deflection, is of:

$$
\sigma=\frac{4 \cdot E \cdot \mathrm{h} \cdot \mathrm{f}_{\max }}{1^{2}}=111,5 \mathrm{MPa} .
$$

So, as a result of implementation of welding operations, there is quite a significant deflection. It does not exceed the regulatory requirements for this type of element $\frac{f_{\max }}{l} \leq \frac{1}{600} \div \frac{1}{700}$ [6], but when performing repair work is necessary to take into account. According to the sample above, other support structures were designed (Table. 1) Taken into account the need for typical elements because their thickness in all cases are the same.

Table. 1. Calculating beam's cross-sections for different loans.

\begin{tabular}{|c|c|c|c|c|c|c|c|c|c|c|}
\hline \hline $\mathrm{P}$, & \multicolumn{3}{|c|}{ Calculated loans } & \multicolumn{3}{|c|}{ Sizes of elements, $\mathrm{mm}$} & \multicolumn{4}{|c|}{ Conditions of strength } \\
\cline { 2 - 3 } & $\begin{array}{c}M_{\Sigma}, \\
\mathrm{MN} \cdot \mathrm{m}\end{array}$ & $Q_{\Sigma}, \mathrm{kN}$ & $\delta_{B}$ & $h_{B}$ & $\delta_{P}$ & $s_{p}$ & $\begin{array}{c}z, \\
\mathrm{~mm}\end{array}$ & $\sqrt{\left(\frac{\sigma}{\sigma_{o}}+\frac{\sigma_{m}}{\sigma_{M o}}\right)^{2}+\left(\frac{\tau}{\tau_{o}}\right)^{2}} \leq 1$ & $\tau_{\text {ext }} \leq\left[\tau^{\prime}\right]$ \\
\hline 50 & 0,077 & 79,06 & 6 & 320 & 10 & 74 & 52,1 & 0,598 & 50,0 \\
\hline 100 & 0,152 & 156,33 & 6 & 500 & 10 & 85 & 54,5 & 0,672 & 90,4 \\
\hline 150 & 0,227 & 233,61 & 6 & 530 & 10 & 140 & 64,4 & 0,639 & 117,2 \\
\hline 200 & 0,302 & 310,87 & 6 & 620 & 10 & 155 & 66,6 & 0,897 & 149,1 \\
\hline
\end{tabular}

As we see the increasing load on cross-bar makes necessary to use of large cross section. In this vertical sheet resistance is provided in all cases. However, for maximum load there is a slight excess of the limit stresses in welds. In this case it is necessary to increase the thickness of the zone beams.
For selected $I$-beam with it liner characteristics the calculation were made to find the level of internal forces, causing shrinkage of the material after welding cycle welding cycle is done. Since the legs and thick welds elements were the same in all cases, the mode options match the options above.

Table 2. Calculations of welding stresses and deformations

\begin{tabular}{|c|c|c|c|c|c|c|c|}
\hline $\begin{array}{c}\mathrm{P}, \\
\mathrm{kN}\end{array}$ & $\begin{array}{c}F_{N}, \\
\mathrm{~mm}^{2}\end{array}$ & $P_{\mathrm{T} \text {-beam.shrinkage }}^{\text {longi. }}, \mathrm{kN}$ & $P_{I-\text { beam shrinkage }}^{\text {longi. }}, \mathrm{kN}$ & $\begin{array}{c}f_{\mathrm{y} \mathrm{T}}, \\
\mathrm{mm}\end{array}$ & $f_{\mathrm{y} \mathrm{I}}, \mathrm{mm}$ & $\begin{array}{c}f_{\mathrm{y} \Sigma}, \\
\mathrm{mm}\end{array}$ & $\begin{array}{c}\sigma_{b d}, \\
\mathrm{MPa}\end{array}$ \\
\hline 50 & 389,9 & 159,93 & 154,16 & 23,85 & 9,31 & 14,54 & 137,3 \\
\hline 100 & 401,5 & 156,87 & 153,63 & 13,24 & 5,52 & 7,72 & 111,5 \\
\hline 150 & 459,1 & 178,57 & 174,04 & 8,42 & 3,34 & 5,07 & 77,5 \\
\hline 200 & 474,8 & 182,62 & 178,61 & 6,68 & 2,69 & 3,98 & 70,8 \\
\hline
\end{tabular}

Thus, increasing the beam cross-section leads to increasing shrinkage forces during welding on the same linear energies. This increases rigidity, which would reduce the total value of construction deformation and value of bending stress that it causes.

Conclusions. Analysis used in pipeline transportation elements overpasses show that the usage of welded beams in repair works allows to satisfy much more exploitation conditions. The calculation and choice of beams geometrical sizes of elements for the case of the overpasses with two pipelines. Learned influences of welding cycle on stress and deformation occurring in the cross-bar. The total welding deformation can be from 4 to $14 \mathrm{~mm}$. Therefore, to satisfy specified position welding deformations should be taken into account.

\section{Література}

1. Дзюбик А.Р. Забезпечення міцності надземного переходу магістрального трубопроводу із врахуванням умов його спорудження / А.Р. Дзюбик, Б.С. Білобран // 10-ий Міжнародний симпозіум українських інженерів-механіків у Львові : праці. - Львів : Вид-во "Кінпатрі" ЛТД - 2013. - C. $22-23$.

2. Дзюбик А. Розрахунок напружено-деформованого стану балкових переходів магістральних трубопроводів чисельними методами / А. Дзюбик, Б. Білобран // Вісник Національного уніних трубопровод верситету "Львівська політехніка" - Сер.: Динаміка, міцність та проектування машин і приладів. ььвів : Вид-во НУ "Львівська політехніка". - 2007. - № 588. - С. 8-12.

3. Магістральні трубопроводи. Будівництво. Лінійна частина. ВБН Надземні переходи. В.2.3-00013741-10:2009

4. Білобран Б.С. Вплив монтажного пружного згину на напружено-деформований стан надземних переходів магістральних нафтопроводів у горах / Б.С. Білобран, А.Р. Дзюбик, С.Р. Яновський // Нафтова і газова промисловість : зб. наук. праць. - 2012. - № 6. - С. 39-42.

5. Білобран Б.С. Спосіб ремонту залізобетонних опор магістральних трубопроводів. - Пат. 84042 Україна, МПК (2013.01) F16L 1/00, F16L 3/00 / Б.С. Білобран, А.Р. Дзюбик, С.Р. Яновський, В.М. Залеський //Заявник і патентовласник НУ "Львівська політехніка", № u 2013 04081; заявл. 02.04.13; опубл. 10.10.13, Бюл. № 19

6. Николаев Г.А. Сварные конструкции. Технология изготовления / Г.А. Николаев, С.А. Куркин, В.А. Винокуров // Автоматизация производства и проектирование сварных конструкций. - М. : Изд-во "Высш. шк.", 1983. - 344 с.

7. Кузьо І.В. Статична рівновага балки змінної жорсткості на пружних опорах з попереднім змішенням / І.В. Кузьо, Л.В. Дзюбик, І.А. Прокопишин // Машинознавство. - 2009. - № 11 (149). 27-30

8. Дзюбик А. Міцність надземних багатопрогонових переходів трубопроводів із врахуванням пружних деформацій опор / А. Дзюбик, Л. Дзюбик // Теорія та практика раціонального проектування, виготовлення і експлуатації машинобудівних конструкцій : тези доп. 3-ї Міжнар. наук.-техн. конф. - Львів. - С. 83.

3. Технологія та устаткування лісовиробничого комплексу 
9. Справочник сварщика / под ред. В.В. Степанова. - М. : Изд-во "Машиностроение", 1982. $-560 \mathrm{c}$.

10. Касаткин Б.С. Напряжения и деформации при сварке / Б.С. Касаткин, В.М. Прохоренко, И.М. Чертов. - К. : Изд-во "Вища шк.", Головне вид-во, 1987. - 246 с.

11. Палаш В.М. Напруження у трубах, з'єднаних зварним кільцевим швом / В.М. Палаш В.М. Юськів, А.Р. Дзюбик // Фізико-хімічна механіка матеріалів : зб. наук. праць. - 2000. - № 4. - C. 95-99.

$$
\text { Надіслано до редакції } 24.02 .2016 \mathrm{p} \text {. }
$$

Дзюбик А.Р., Палаш В.М., Назар І.Б., Дзюбик Л.В., Палаш Р.В. Застосування зварних опорних вузлів під час ремонту надземних переходів магістральних трубопроводів

Проаналізовано наявні елементи опорних вузлів надземних переходів у трубопровідному транспорті. Вивчено експлуатаційні навантаження, які виникають у надземних ділянках магістральних трубопроводів із використанням математичної моделі, що враховує можливість вертикального зміщення опорних вузлів. Запропоновано використовувати зварну балку двотаврового перерізу для ригеля опори. Проведено розрахунок прийнятої балки та вибір геометричних розмірів ії елементів залежно від прикладеного навантаження. Досліджено вплив зварювального циклу на напруження та деформації, що виникають під час виготовлення металевого ригеля двотаврового перерізу.

Ключові слова: опора, трубопровід, напруження, зварний шов, міцність, несна здатність.

Дзюбык А.Р., Палаши В.Н., Назар И.Б., Дзюбык Л.В., Палаш Р.В. Применение сварных опорных узлов при ремонте надземных переходов магистральных трубопроводов

Проанализированы существующие элементы опорных узлов надземных переходов в трубопроводном транспорте. Изучены эксплуатационные нагрузки, возникающие в надземных участках магистральных трубопроводов с использованием математической модели, учитывающей возможность вертикального смещения опорных узлов. Предложено использовать сварную балку двутаврового сечения для ригеля опоры. Проведен расчет балки и выбор геометрических размеров ее элементов в зависимости от приложенной нагрузки. Исследовано влияние сварочного цикла на напряжения и деформации, возникающие при изготовлении металлического ригеля двутаврового сечения.

Ключевые слова: опора, трубопровод, напряжение, сварной шов, прочность, несущая способность.

\section{УДК 630.32.002.5}

\section{ВИКОРИСТАННЯ ПЛАСТИКОВИХ ЛОТКОВИХ СИСТЕМ \\ ДЛЯ ПЕРВИННОГО ТРАНСПОРТУВАННЯ ДЕРЕВИНИ}

\section{В.В. Кий ${ }^{1}$, І.Ф. Коляджин ${ }^{2}$}

Порушено проблему технологічного освоєння сухостійних ялинових насаджень на схилах Карпат. Проаналізовано можливі засоби первинного транспортування деревини під час їх розроблення. Оцінено пошкодження, які виникають унаслідок використання різних засобів трелювання деревини та ефективності їх використання. Обгрунтовано доцільність використання пластикових лоткових систем на трелювальні в гірських умовах під час заготівельних робіт у сухостійних насадженнях.

Ключові слова: лоткові системи, транспортування, сухостійні насадження, технологія, деревина.

доц. В.В. Кий, канд. техн. наук - НЛТУ України, м. Львів;

директор І.Ф. Коляджин, канд. с.-г. наук - державне підприємство "Брошнівске лісове господарство"
Постановка проблеми та аналіз основних публікацій. Україна належить до європейських країн із значними запасами деревної сировини. Загальна площа лісів становить близько 11 млн га, з яких 20 \% лісосировинних запасів зосереджено в гірському Карпатському регіоні [1]. Ліси Карпат мають надзвичайно важливе водоохоронне, гідрокліматичне, протиерозійне та санітарно-гігієнічне значення. Вони регулюють поверхневий стік і помітно впливають на гідрологічний режим Дністра, Пруту, Тиси та їхніх приток. Лісові багатства Карпат відіграють важливу роль у розвитку національного господарства. Лісозабезпеченість у розрахунку на одну особу становить тут 0,42 га і 73,8 м³ деревини [2]. Однак, варто зазначити, що упродовж останніх років на території Карпат відбувається інтенсивне всихання ялинових насаджень. I як наголошено у Національних доповідях про стан техногенної та природної безпеки в Україні, після 2005 р. всихання ялинників Карпат трактують як стихійне лихо: "Для Карпатського регіону значною проблемою залишається всихання похідних ялинників, тобто, таких, які ростуть у невідповідних лісорослинних умовах. ... Всихання ялинників у Карпатах розглядають вже як стихійне лихо, причиною якого є зниження природного імунітету та ослаблення насаджень внаслідок глобального потепління клімату, техногенного забруднення атмосфери і грунту та невідповідної лісогосподарської діяльності в минулому" [3].

Більшість науковців схиляються до думки, що будь-яка закономірність всихання ялинників щодо розміщення на схилах (підніжжя, середина схилу, верхівка), площ всихання, орієнтації за сторонами світу відсутня [4-6]. Отже, проблема масштабного і незакономірного всихання ялинових лісів в Українських Карпатах є актуальною і потребує раціонального й ефективного рішення, одним з яких є своєчасне прибирання всохлих дерев.

Постановка завдання. Треба зауважити також, що застосовувана зараз у Карпатах технологія лісозаготівлі призводить до значних негативних змін у лісове середовище і хід лісовідновних процесів. Технологічний процес лісозаготівлі у Карпатах головно грунтується на наземному трелюванні, яке здійснюють примітивно облаштованими трелювальними волоками на значні віддалі. Це призводить до значних, часто незворотних, екологічних пошкоджень: руйнування грунтового покриву, забруднення водних потоків, активізації ерозійних процесів і пошкодження деревостану [8].

Ситуація посилюється у разі потреби виконання санітарних вибірковиих рубок, як наприклад прибирання сухостійних насаджень, коли невелику кількість всохлих дерев потрібно прибрати за короткий час, а їх розміщення по території лісомасиву довільне. Тоді застосування традиційної техніки і технології призводить до значних пошкоджень навколишнього середовища, особливо це стосується операції первинного транспортування заготовленої деревини. Потрібно шукати нові, ефективні технологічні способи розроблення ділянок всохлої деревини, які забезпечили б найменший негативний вплив на довкілля.

Виклад основного матеріалу. Транспортування деревини є однією із найвитратніших та екологічно найнебезпечніших технологічних операцій у виробничому процесі заготівлі деревини. Відомі три принципово різні за способом транспортування деревини технології гірської лісозаготівлі: наземне тран-

$\begin{array}{lr}\text { 3. Технологія та устаткування лісовиробничого комплексу } & 239\end{array}$ 